\title{
Strategies for the prevention and treatment of sudden cardiac death
}

\author{
This article was published in the following Dove Press journal: \\ Open Access Emergency Medicine \\ 9 December 2010 \\ Number of times this article has been viewed
}

\section{Emad F Aziz \\ Fahad Javed \\ Balaji Pratap \\ Eyal Herzog}

The Advanced Cardiac Admission Program, St Luke's-Roosevelt Hospital Center, University Hospital of Columbia University, College of Physicians and Surgeons,

New York, NY, USA
Correspondence: Eyal Herzog

Director of Cardiac Care Unit,

St Luke's Roosevelt Hospitals,

Columbia University College

of Physicians and Surgeons,

I I I Amsterdam Ave, New York,

NY 10025 , USA

$\mathrm{Tel}+|2| 2523264 \mid$

Fax + I $2 \mid 252343$ II

Email eherzog@chpnet.org
Abstract: Cardiovascular diseases account for $40 \%$ of all deaths in the West. Sudden cardiac death (SCD) is a major health problem affecting over 300,000 patients annually in the United States alone. Presence of coronary artery disease (CAD), usually in the setting of diminished left ventricular ejection fraction, is still the single major risk factor for SCD. Additionally, acute myocardial ischemia, structural cardiac defects, anomalous coronary arteries, cardiomyopathies, genetic mutations, and ventricular arrhythmias are all attributed to SCD, demonstrating the perplexity of this condition. With the recent advancements in cardiovascular medicine, the incidence of SCD is expected to increase steeply as the prevalence of CAD and heart failure is uprising in general population. Considering SCD, the major challenge confronting contemporary cardiology, multiple strategies for prevention against SCD have been developed. $\beta$-blockers have been shown to reduce the risk of SCD, whereas implantable cardioverter-defibrillator devices are found to be effective at terminating the malignant arrhythmias. In recent years, multiple clinical trials were carried out to identify patients who may benefit from preventive intervention, including medical therapy and automatic cardioverter-defibrillator implantations. This review article provides insight into the advanced strategies for the prevention and treatment of SCD based on the data available in medical literature to date.

Keywords: risk stratification, sudden cardiac death, prevention, treatment

\section{Introduction}

Sudden cardiac death (SCD), also known as sudden arrest, is a major health problem worldwide. ${ }^{1}$ Estimates for the United States range from less than 200,000 to more than 450,000 SCDs annually, with the most widely used estimates in the range of $300,000-350,000$ SCDs annually. ${ }^{2,3}$ It is usually defined as an unexpected death from a cardiac cause occurring within a short time in a person with or without preexisting heart disease because of abrupt loss of heart function (cardiac arrest). A dynamic triggering factor usually interacts with an underlying heart disease, either genetically determined or acquired, and the final outcome is the development of lethal tachyarrhythmias or, less frequently, bradycardia. ${ }^{4}$

There is no comprehensible consensus on the definition of SCD, which is witnessed in only two-thirds of cases. Because the duration of symptoms preceding the terminal event usually defines the sudden nature of death, World Health Organization defines SCD as unexpected death within 1 hour of symptom onset if witnessed or within 24 hours of the person having been observed alive and symptom-free if unwitnessed. ${ }^{5}$ Exclusion of noncardiac causes, such as pulmonary embolus or drug overdose, is also critical since sudden cardiac arrhythmias may be the final common pathway in these disease states as well. 
According to the Framingham Heart Study, 13\% of deceased have died of sudden death during a 20 -year follow-up. ${ }^{6}$ In more than $80 \%$ of cases, sudden death is caused by coronary disease. ${ }^{7}$ The mechanism of sudden death is ventricular fibrillation (VF) in $65 \%-85 \%$, ventricular tachycardia (VT) in 7\%-10\%, and electromechanical dissociation in $20 \%-30 \%$. Pathoanatomical finding can be positive on myocardium-like fibrosis, edema, individual necrosis, and cell infiltration, or it can be unchanged.

\section{Risk factors}

About $80 \%$ of individuals who suffer SCD have coronary heart disease; the epidemiology of SCD to a great extent parallels that of coronary heart disease. Based on the recently published data, the following variables have been associated with patients at higher risk of SCD: 1) syncope at the time of the first documented episode of arrhythmia, 2) New York Heart Association (NYHA) class III or IV, 3) VT/fibrillation occurring early after myocardial infarction (MI; 3 days to 2 months), and 4) history of previous MI. ${ }^{8}$ Other factors such as age, hypertension, left ventricular hypertrophy (LVH), intraventricular conduction block, elevated serum cholesterol, glucose intolerance, decreased vital capacity, smoking, relative weight, and heart rate also are postulated in identifying individuals at risk for SCD. ${ }^{9-11}$ Even family history of MI has been reported to be associated with the risk of primary cardiac arrest. ${ }^{12}$ Another entity of patients at highest risk for early SCD is those with hereditary ion channel or myocardial defects, such as a long QT syndrome (LQTS) or short QT syndrome (SQTS), hypertrophic cardiomyopathy (HCM), and arrhythmogenic right ventricular dysplasia (ARVD).

\section{Etiology}

\section{Coronary artery disease}

Coronary artery disease (CAD) is the most common and frequent cause of SCD in the western world. ${ }^{13,14}$ The incidence of ventricular tachyarrhythmias during acute ST-segment elevation $\mathrm{MI}$ is $10 \%$, with $85 \%$ of these cases occurring within the first 48 hours. ${ }^{15}$ Mortality due to acute episodes of MI is high outside of the hospital and most deaths occur within 1 hour of symptom onset, usually associated with acute occlusions of left coronary circulation with accompanying ventricular arrhythmias. ${ }^{16}$ Abrupt changes in regional myocardial blood flow due to alterations in coronary artery structure and/or function, such as spasm, platelet thrombi, dissection, or plaque rupture, can provoke acute ischemia that can have a direct effect on the electrophysiologic properties of the heart, leading to ventricular arrhythmias. ${ }^{17}$ Interestingly, old healed infarctions are present in $\geq 50 \%$ of hearts of SCD victims at autopsy and in those of survivors of cardiac arrest. ${ }^{18}$ Size of myocardial scar has recently been correlated with inducibility of ventricular arrhythmias by programmed electrical stimulation. ${ }^{19}$

\section{Anomalous origin of coronary arteries}

One of the important, but rare, causes of SCD is the anomalous origin of coronary arteries, especially in adolescents and young adults under the age of 35 years. ${ }^{20} \mathrm{In}$ a study by Eckart et al, in 39 deaths attributed to coronary artery pathology, 21 of those patients were found to have anomalous coronary origin (ACO) at autopsy. ${ }^{20}$ The most common pathology seen in $\mathrm{ACO}$ is a left main coronary artery takeoff from the right coronary sinus with a course between the aorta and the right ventricular (RV) outflow tract. Still, the overall incidence of coronary artery anomalies remains low, requiring a high index of suspicion to make a diagnosis. The biggest factors to help make the diagnosis of ACO in a young patient may be the presence of prodromal symptoms. Although transthoracic echocardiography can visualize the origins, computed tomography or magnetic resonance imaging (MRI) coronary angiography is more sensitive and specific for ACO.

\section{Cardiomyopathies}

Cardiomyopathies represent the second major group of patients who experience SCD. LV dysfunction is a major independent predictor of total and sudden cardiac mortality in patients with ischemic and nonischemic cardiomyopathy. ${ }^{1}$ Studies have shown that in survivors of cardiac arrest who have a LV ejection fraction $(\mathrm{EF})<30 \%$, the risk of SCD exceeds $30 \%$ over $1-3$ years if the patients do not have inducible VT, whereas it ranges between $15 \%$ and $50 \%$ in those who have inducible ventricular tachyarrhythmias despite therapy with drugs that suppress the inducible arrhythmias. ${ }^{21,22} \mathrm{SCD}$ in this patient population may be due to acute or progressive pump failure or primary arrhythmia, leading to electrical or hemodynamic instability and death.

$\mathrm{HCM}$ is a genetically heterogeneous heart muscle disorder characterized by myocardial hypertrophy in the absence of abnormal loading conditions. It has a prevalence of $0.2 \% \approx 1$ in 500 young adults, and although it is well-known that patients with HCM die suddenly from ventricular arrhythmia, recent data suggest that the overall risk is relatively small with annual SCD rates of $1 \%$ or less. ${ }^{23}$ Mutations in the genes encoding the $\beta$-myosin heavy chain (MYH7), myosin-binding protein C (MYBPC3), and cardiac 
troponin-T (TNNT2) are responsible for more than $45 \%$ of familial HCM, and $88 \%$ of disease-causing genes reside on these three loci. MYH7 mutations create highly penetrant disease phenotypes with severe myocardial hypertrophy at a young age, heart failure, and unfavorable prognosis for SCD. ${ }^{24}$ The goal for physicians is to diagnose that small percentage of at-risk patients in order to point them toward potentially lifesaving therapy with implantable cardioverterdefibrillators (ICDs). In 2003, the American College of Cardiology (ACC) and the European Society of Cardiology (ESC) recommended that all patients with HCM should be assessed using an algorithm based on a small number of readily determined clinical parameters that are thought to reflect the severity of the underlying myocardial disease and therefore the risk of SCD. ${ }^{25}$ Christiaans et $\mathrm{al}^{26}$ performed a systematic literature review of recommended "major" and "possible" clinical risk markers for SCD in HCM, and among these clinical parameters were:

1. Prior aborted cardiac arrest (VF) or spontaneous sustained VT, with a reported 7 -year mortality rate of $33 \%{ }^{27}$ or a 5 -year SCD or ICD discharge rate of $41 \%,{ }^{28}$

2. Nonsustained VT (NSVT), proved to be a significant independent risk factor for SCD, especially in the young; ${ }^{29-31}$ the average reported hazard ratio (HR) for NSVT was 2.89 (95\% confidence interval [CI]: 2.21-3.58);

3. Unexplained syncope; three studies reported a significant increase in SCD in patients with unexplained syncope; ${ }^{31-33}$ the average reported HR for unexplained syncope was 2.68 (95\% CI: 0.97-4.38);

4. Extreme left ventricle thickness $\geq 30 \mathrm{~mm}$; there is no clear consensus among all studies; however, the average reported HR for extreme LVH was 3.10 (95\% CI: 1.81-4.40);

5. Abnormal blood pressure response (ABPR) to exercise testing; some of the included studies found significantly more SCD in HCM patients with an ABPR, ${ }^{33}$ but in one study, the risk was only increased for patients aged 50 years or younger; ${ }^{31}$ the average reported HR for ABPR was 1.30 (95\% CI: 0.64-1.96); and

6. Family history of premature SCD; three recent studies demonstrated that family history of SCD (FHSCD) was an independent but weak predictor for $\mathrm{SCD} ;{ }^{30,31}$ the average reported HR for FHSCD was 1.27 (95\% CI: 1.16-1.38).

ARVD is a chronic disease of progressive fibrofatty infiltration of the right ventricle that is commonly associated with ventricular arrhythmias responsible for sudden death in young individuals and adults; it has been shown that up to $50 \%$ of arrhythmogenic RV cardiomyopathy (ARVC) cases are famil- ial, with significant involvement in first- and second-degree relatives. ${ }^{34}$ The estimated prevalence of the disease is $1: 5,000$, with the mortality rate being $2 \%-4 \%$ per year. ${ }^{35}$ It is a Mendelian autosomal dominant trait with incomplete penetrance. Since ARVC is often found in association with diffuse palmoplantar keratoderma and woolly hair, genetic classification is divided into desmosomal (Naxos disease) and extradesmosomal genes. Twelve genetic loci have been discovered so far, and mutations were documented in eight different genes. Different mutations have been detected in genes encoding desmosomal proteins. ${ }^{36}$ Naxos disease is the triad of ARVC, woolly hair, and diffuse keratoderma over the pressure areas of the palms and soles. The causal mutation has been identified to be a two-base-pair deletion in the plakoglobin gene of the desmosome (JUP) in the locus $17 \mathrm{q} 21 .^{37,38}$ Desmoplakin (DSP) was also the first gene isolated in autosomal dominant ARVC. Using a candidate gene approach focusing on the desmosome, causal mutations have since been identified in plakophilin-2 (PKP2), desmoglein-2 (DSG2), and desmocollin-2 (DSC2). ${ }^{39}$

Because most mutations in ARVC are "private" mutations, more than $50 \%$ of affected individuals do not harbor a mutation in one of the known causal genes, but failure to establish this genetic diagnosis does not exclude the disease. ${ }^{40}$ However, in a suspicious borderline patient, identification of a causal gene may allow confirmation of the diagnosis in a borderline index case. Bauce et al insist that should these patients have any single mutation, it warrants further gene mutation screening on the same gene, with attention given to the three major desmosomal genes: PKP2, DSP, and DSG2. ${ }^{36}$

The electrocardiogram (ECG) may show anterior precordial T-wave inversion, particularly in lead V2 and/or a QRS complex duration $\geq 110$ milliseconds in the right precordial leads, epsilon waves, which are reproducible small deflections seen just beyond the QRS complex in lead V1 or V2 also has been documented. ${ }^{41}$ The left ventricle and ventricular septum can be involved in 50\%-67\% of cases, often later in the disease, representing a poor prognosis. ${ }^{15}$ Exercise can precipitate VT in these patients, and the most common arrhythmia is sustained or nonsustained VT originating from the right ventricle, typically with a left bundle branch block pattern and inferior axis. Patients with ARVD typically present with palpitations (27\%), syncope (26\%), or SCD (23\%) and usually present between the second and the fifth decade of life. ${ }^{42}$ The gold standard test for diagnosis is myocardial biopsy, showing fibrofatty infiltration; however, RV angiography or MRI are becoming acceptable imaging modalities. Table 1 lists the criteria for diagnosis of ARVD according to the progress 
Table I Criteria for the diagnosis of ARVD: diagnosis depends on two major and two minor criteria

\begin{tabular}{|c|c|c|}
\hline Criteria & Major & Minor \\
\hline Family history & $\begin{array}{l}\text { Familial disease confirmed at } \\
\text { necropsy or surgery }\end{array}$ & $\begin{array}{l}\text { Family history of premature sudden } \\
\text { death }(<35 \text { y) caused by suspected ARVD } \\
\text { or family history of ARVD }\end{array}$ \\
\hline $\begin{array}{l}\text { ECG (depolarization/conduction } \\
\text { abnormalities) }\end{array}$ & $\begin{array}{l}\text { Epsilon waves or prolongation of the } \\
\text { QRS complex ( } \geq 110 \mathrm{~ms}) \text { in the } \\
\text { right precordial leads }(\mathrm{VI}-\mathrm{V} 3)\end{array}$ & Late potentials seen on signal averaged ECG \\
\hline Repolarization abnormalities & - & $\begin{array}{l}\text { Inverted } T \text { waves in the right precordial leads } \\
\text { in patients }>12 \text { in the absence of right } \\
\text { bundle branch block }\end{array}$ \\
\hline Tissue characterization of walls & $\begin{array}{l}\text { Fibrofatty replacement of myocardium } \\
\text { on endomyocardial biopsy }\end{array}$ & - \\
\hline $\begin{array}{l}\text { Global or regional dysfunction and } \\
\text { structural alterations }\end{array}$ & $\begin{array}{l}\text { Severe dilatation and reduction of RVEF } \\
\text { with minimal LV involvement } \\
\text { Localized RV aneurysms } \\
\text { Severe segmental dilation of the RV }\end{array}$ & $\begin{array}{l}\text { Mild global RV dilation or ejection fraction } \\
\text { reduction with normal LV } \\
\text { Mild segmental dilation of the RV } \\
\text { Regional RV hypokinesia }\end{array}$ \\
\hline Arrhythmia & - & $\begin{array}{l}\text { Left bundle branch lack type ventricular } \\
\text { tachycardia (sustained and nonsustained); } \\
\text { ECG, Holter, exercise testing } \\
\text { Frequent ventricular extrasystoles } \\
\text { (more than I,000/24 h) (Holter) }\end{array}$ \\
\hline
\end{tabular}

Abbreviations: ARVD, arrhythmogenic right ventricular dysplasia; ECG, electrocardiogram; RV, right ventricular; RVEF, right ventricular ejection fraction; LV, left ventricular.

report of the modification for the diagnosis of ARVD. These patients may also show abnormalities in voltage mapping of the RV. If ARVD is clinically suspected, then referral to an ARVD tertiary care center or registry site may be appropriate. Treatment of ARVD may include antiarrhythmic drugs, radiofrequency catheter ablation, and ICD placement.

\section{Left ventricular hypertrophy}

LV hypertrophy is independently attributed to a high cardiovascular mortality and, in particular, to SCD in patients who had a history of hypertension or ischemic heart disease. ${ }^{43}$ Multiple disease states can result in hypertrophy, including valvular heart disease, obstructive and nonobstructive HCM, primary pulmonary hypertension with RV hypertrophy, and various congenital heart disorders. LV hypertrophy modulates arrhythmia susceptibility via electrical heterogeneity from local scarring, which is postulated to result from local subendocardial ischemia and subsequent remodeling. Interestingly, myocardial scarring is found mostly in hypertrophied regions, ${ }^{44}$ and the extent of scarring has been correlated with clinical markers of sudden death, including ventricular wall thickness. ${ }^{45}$

\section{Infiltrative myocardial diseases}

Primary amyloidosis, a protein deposition disorder, may involve the heart in one-third of cases. Sudden death is common in these patients with involvement of heart. Although the sinus node is the most common site of amyloid deposition, infra-His conduction is also commonly affected and is associated with malignant arrhythmias. ${ }^{46}$ Amyloid deposition in the ventricular myocardium leads to electrical heterogeneity and delayed activation, which are risk factors for sudden death. ${ }^{47}$

\section{Congenital cardiac anomalies}

Tetralogy of Fallot, transposition of the great arteries, aortic stenosis, and pulmonary vascular obstruction are the major congenital anomalies, which are associated with higher risk of SCD. SCD has also been described as a late complication after surgical repair of complex congenital cardiac lesions, such as Tetralogy of Fallot and transposition of the great arteries, and in patients with primary or secondary pulmonary hypertension. In Tetralogy of Fallot, QRS prolongation relates to $\mathrm{RV}$ size and predicts patients at risk for $\mathrm{SCD} .^{48}$

\section{$S C D$ in young competitive athletes}

The true incidence of SCD in young athletes is not known with certainty. In the United States, it has been reported as 1:200,000 young athletes per year in Minnesota high schools. ${ }^{49}$ A prospective study in Italy has reported an incidence of SCD of 2.1 per 100,000 athletes per year from cardiovascular diseases. The most common causes are inherited cardiovascular disorders. In the United States, HCM accounts for $36 \%$ of the total deaths, followed by congenital coronary artery anomalies, which accounts for $17 \%$ of the total deaths. ARVC and ion channelopathies represent $4 \%$ and 3\% of the total deaths, respectively. ${ }^{50,51}$ But in Europe, 
specifically in the Veneto region of Italy, the most common cause of SCD in athletes is ARVC, accounting for $22 \%$ of the total deaths, followed by anomalous origin of coronary arteries, accounting for $12 \%$ of the total deaths.

\section{Primary electrophysiologic abnormalities}

Patients with primary electrophysiologic abnormalities correspond to a group in whom mechanical function of the myocardium is normal and an electrophysiologic derangement represents the primary cardiac problem.

\section{Long QT syndrome}

The LQTS is an electrical disorder of ventricular repolarization, characterized by an increased risk of life-threatening polymorphic ventricular arrhythmias (torsade de pointes) and $\mathrm{SCD}$. Because torsades de pointes can cause seizures due to cerebral anoxia, LQTS is important to consider in patients with apparent drug-resistant seizure disorders..$^{52}$ Both emotional stress and exercise have been found to be triggering factors of arrhythmias and syncope in these patients possibly via an increase in catecholamine concentrations. ${ }^{53,54}$ LQTS is a heterogeneous disease that may be congenital or acquired. Both types may have a genetic basis. These syndromes serve as a Rosetta stone for the understanding of inherited ion-channel disorders, leading to life-threatening cardiac arrhythmias. Ionic abnormal changes mainly affecting $\mathrm{K}^{+}, \mathrm{Na}^{+}$, or $\mathrm{Ca}^{2+}$ currents, which either prolong or shorten ventricular repolarization, can create a substrate of electrophysiologic heterogeneity that predisposes to the development of ventricular tachyarrhythmias and sudden death. Treatment of LQTS varies according to different genotypes. For example, patients with LQT1 are very responsive to $\beta$-blockers, whereas those with LQT3 are usually unresponsive.

Risk stratification for patients with LQTS: LQTS outcome varies and is prejudiced by the duration of the QTc interval, environmental factors, age, genotype, and response to treat- ment. ${ }^{55,56}$ Ventricular arrhythmia is more frequent in LQTS1 and LQTS2, but is more severe in LQTS3. ${ }^{57}$ Women are more susceptible to malignant arrhythmia during the postpartum period. ${ }^{58}$ The triggers for lethal cardiac events are listed in Table $2.59,60$

High-risk patients with LQTS include those with the following:

1. Congenital deafness (Jervell-Lange-Nielsen syndrome). ${ }^{61}$

2. Recurrent syncope due to malignant ventricular tachyarrhythmia.

3. Family history of sudden death.

4. QTc $>500$ milliseconds.

5. 2:1 atrioventricular block.

6. T-wave electric alternans.

7. LQTS3 genotype.

Priori et a ${ }^{55}$ reported that the probability of presenting a major event (syncope, cardiac arrest, sudden death) before the age of 40 years is high $(>50 \%)$ when QTc is >500 milliseconds in LQTS1, LQTS2, and males with LQTS3. Cardiac arrest survivors and patients with recurrent syncope despite $\beta$-blocker treatment usually receive implantation of ICD. ${ }^{62,63}$

Congenital LQTS: Congenital LQTS accounts for 3,0004,000 sudden childhood deaths per year in the United States. ${ }^{64}$ The disease incidence is estimated at 1 per $7,000-10,000 .{ }^{54}$ Although torsades is the most common arrhythmia, premature ventricular complexes, monomorphic VT, bradycardia, and even atrioventricular block have also been observed in some patients with this disorder. QT prolongation was long recognized to have a familial inheritance pattern, but only recently have the genetics been elucidated. Mutations in seven genes have been identified, but three types of mutations are most involved in arrhythmias: LQT1 (42\%), LQT2 (45\%), and LQT3 (8\%). ${ }^{65}$

Acquired LQTS: Acquired LQTS usually results from electrolyte imbalances or drug therapy. Intracellular deficiencies of potassium and magnesium prolong myocardial

Table 2 LQTS types: channelopathy, frequency, triggers, and ECG morphology

\begin{tabular}{|c|c|c|c|c|c|}
\hline Types & Current & $\begin{array}{l}\text { Functional } \\
\text { effect }\end{array}$ & $\begin{array}{l}\text { Frequency } \\
\text { among LQTS }\end{array}$ & Triggers lethal cardiac event & ECG \\
\hline LQTSI & K & $\downarrow$ & $30 \%-35 \%$ & $\begin{array}{l}\text { Exercise }(68 \%) \text {, emotional } \\
\text { stress (14\%), sleep, repose ( } 9 \%) \text {, } \\
\text { others ( } 19 \%)\end{array}$ & \\
\hline LQTS2 & $\mathrm{K}$ & $\downarrow$ & $25 \%-30 \%$ & $\begin{array}{l}\text { Exercise }(29 \%), \text { emotional } \\
\text { stress }(49 \%) \text {, sleep, repose } \\
(22 \%)\end{array}$ & \\
\hline LQTS3 & $\mathrm{Na}$ & $\uparrow$ & $5 \%-10 \%$ & $\begin{array}{l}\text { Exercise }(4 \%) \text {, emotional } \\
\text { stress (I2\%), sleep, repose } \\
(64 \%) \text {, others }(20 \%)\end{array}$ & 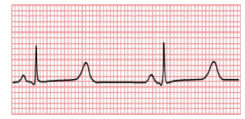 \\
\hline
\end{tabular}

Abbreviation: ECG, electrocardiogram; LQTS, long QT interval syndrome. 
Table 3 Role of ICDs in the prevention against SCD: multiple prospective randomized multicenter clinical trials

\begin{tabular}{|c|c|c|c|c|}
\hline Name of trials & Sample size & Type of study & Population & Outcome \\
\hline AVID & 1,016 & $\begin{array}{l}\text { Secondary } \\
\text { prevention }\end{array}$ & $\begin{array}{l}\text { Survived VT/VF/cardiac arrest; } \\
\text { VT with syncope; VT with } \\
\text { LVEF } \leq 40 \%\end{array}$ & $\begin{array}{l}31 \% \text { reduction in total mortality with } \mathrm{ICD} \\
\text { therapy }(\mathrm{HR}, 0.66 ; 95 \% \mathrm{Cl}: 0.5 \mathrm{I}-0.85 ; P<0.02)\end{array}$ \\
\hline MADIT & 196 & $\begin{array}{l}\text { Primary } \\
\text { prevention }\end{array}$ & $\begin{array}{l}\text { Prior MI; LVEF } \leq 35 \% \text {; } \\
\text { asymptomatic NSVT; NYHA } \\
\text { class I-III; inducible VT refractory } \\
\text { to IV procainamide on EP study }\end{array}$ & $\begin{array}{l}54 \% \text { reduction in total mortality with ICD } \\
\text { therapy (HR, } 0.46 ; 95 \% \mathrm{Cl}: 0.26-0.92 ; \\
P=0.009)\end{array}$ \\
\hline MADIT II & 1,232 & $\begin{array}{l}\text { Primary } \\
\text { prevention }\end{array}$ & Prior MI; LVEF $\leq 30 \%$ & $\begin{array}{l}31 \% \text { reduction in total mortality with } I C D \\
\text { therapy }(H R, 0.69 ; 95 \% \mathrm{Cl}: 0.51-0.93 ; P=0.02)\end{array}$ \\
\hline SCD-HeFT & 2,521 & $\begin{array}{l}\text { Primary } \\
\text { prevention }\end{array}$ & $\begin{array}{l}\text { NYHA class II/III CHF (ischemic } \\
\text { and nonischemic); LVEF } \leq 35 \%\end{array}$ & $\begin{array}{l}\text { Overall: } 23 \% \text { reduction in mortality with ICD } \\
\text { therapy }(P=0.007) \\
\text { Ischemic heart disease: reduction in mortality } \\
\text { with ICD therapy }(P=0.05) \mathrm{HR}, 0.77 ; 97.5 \% \\
\mathrm{Cl}: 0.62-0.96\end{array}$ \\
\hline DEFINITE & 458 & $\begin{array}{l}\text { Primary } \\
\text { prevention }\end{array}$ & $\begin{array}{l}\text { Nonischemic dilated } \\
\text { cardiomyopathy; } \text { LVEF } \leq 36 \% \\
\text { NSVT or PVCs }\end{array}$ & $\begin{array}{l}\text { Reduction in total mortality with ICD therapy } \\
(P=0.08) ; 35 \% \text { reduction in death from } \\
\text { arrhythmia with ICD therapy }(P=0.006) \mathrm{HR} \text {, } \\
0.65 ; 95 \% \mathrm{Cl}: 0.40-1.06\end{array}$ \\
\hline CABG PATCH & 900 & $\begin{array}{l}\text { Primary } \\
\text { prevention }\end{array}$ & $\begin{array}{l}\text { Patients scheduled for CABG; } \\
\text { LVEF } \leq 35 \% \text {; positive signal } \\
\text { averaged ECG result }\end{array}$ & $\begin{array}{l}\text { No reduction in total mortality with ICD } \\
\text { therapy (HR, I.07; } 95 \% \mathrm{Cl}: 0.8 \mathrm{I}-\mathrm{I} .42 \\
P=0.64)\end{array}$ \\
\hline DINAMIT & 674 & $\begin{array}{l}\text { Primary } \\
\text { prevention }\end{array}$ & $\begin{array}{l}\text { Recent MI (within 4-40 days), } \\
\text { LVEF } \leq 35 \% \text {; impaired cardiac } \\
\text { autonomic modulation (heart } \\
\text { rate variability) }\end{array}$ & $\begin{array}{l}\text { No reduction in death from any cause with } \\
\text { ICD therapy }(P=0.66) ; 50 \% \text { reduction in risk } \\
\text { of arrhythmic death with ICD therapy } \\
(P=0.009) ; \mathrm{HR}, \mathrm{I} .08 ; 95 \% \mathrm{Cl}: 0.76-1.55\end{array}$ \\
\hline COMPANION & $\mathrm{I}, 520$ & CRT study & $\begin{array}{l}\text { NYHA class III/IV; LVEF } \leq 35 \% \text {; } \\
\text { QRS interval } \geq 120 \mathrm{~ms} \text {; } \\
\text { hospitalization for CHF } \\
\text { within } 12 \mathrm{mo}\end{array}$ & $\begin{array}{l}24 \% \text { reduction in total mortality with CRT } \\
\text { alone }(P=0.06) ; 36 \% \text { reduction in mortality } \\
\text { with } C R T / I C D(P=0.003) ; \mathrm{HR}, 0.64 ; 95 \% \mathrm{Cl} \text { : } \\
0.48-0.86\end{array}$ \\
\hline CARE-CHF & 813 & CRT study & $\begin{array}{l}\text { NYHA class III/IV; LVEF } \leq 35 \% \text {; } \\
\text { LVEDD } \leq 30 \mathrm{~mm} \text {; QRS } \\
\text { interval } \geq 120 \mathrm{~ms} \text {; if QRS } \\
\text { interval I } 20-149 \mathrm{~ms} \text {, additional } \\
\text { criteria for dyssynchrony }\end{array}$ & $\begin{array}{l}\text { Reduction in all-cause mortality with CRT vs } \\
\text { conventional therapy }(P<0.002) \text {; CRT } \\
\text { reduced the interventricular mechanical delay, } \\
\text { end-systolic volume index, and area of the } \\
\text { mitral regurgitant jet; increased LVEF; and } \\
\text { improved symptoms and quality-of-life scores } \\
(P<0.0 \text { I) HR, } 0.64 ; 95 \% \mathrm{Cl}: 0.48-0.85\end{array}$ \\
\hline MADIT-CRT & 1,820 & CRT study & $\begin{array}{l}\text { Ischemic or nonischemic } \\
\text { cardiomyopathy, LVEF } \leq 30 \% \text {, } \\
\text { QRS interval } \geq 130 \mathrm{~ms} \text {; NYHA } \\
\text { class I/II }\end{array}$ & $\begin{array}{l}34 \% \text { relative reduction in the risk of all-cause } \\
\text { mortality or first heart failure event }(P=0.00 \mathrm{I}) \text {; } \\
\text { HR } 0.66 ; 95 \% \mathrm{Cl}: 0.52-0.84\end{array}$ \\
\hline $\mathrm{CASH}$ & 288 & $\begin{array}{l}\text { Secondary } \\
\text { prevention }\end{array}$ & Survived VT/VF/cardiac arrest & $\begin{array}{l}23 \% \text { reduction in total mortality with } \mathrm{ICD} \\
\text { therapy }(\mathrm{HR}, 0.82 ; 95 \% \mathrm{Cl}: 0.60-1.1 \mathrm{I} ; P=0.08)\end{array}$ \\
\hline CIDS & 659 & $\begin{array}{l}\text { Secondary } \\
\text { prevention }\end{array}$ & $\begin{array}{l}\text { Survived VT/VF/cardiac arrest; } \\
\text { VT with syncope; VT with } \\
\text { LVEF } \leq 35 \% \text { and cycle } \\
\text { length } \leq 400 \mathrm{~ms}\end{array}$ & $\begin{array}{l}33 \% \text { reduction in death from any cause with } \\
I C D \text { therapy }(P=0.14) \text {; reduction in risk } \\
\text { of death from arrhythmia with ICD therapy } \\
(P=0.09) \mathrm{HR}, 0.85 ; 95 \% \mathrm{Cl}: 0.67-\mathrm{I} .10\end{array}$ \\
\hline
\end{tabular}

Abbreviations: ICD, implantable cardioverter defibrillators; AVID, antiarrhythmic vs implantable defibrillator; VT, ventricular tachycardia; VF, ventricular fibrillation; LVEF, left ventricular ejection fraction; CIDS, Canadian Implantable Defibrillator Study; CASH, Cardiac Arrest Study Hamburg; CHF, congestive heart failure; CABG, coronary artery bypass graft; COMPANION, Comparison of Medical Therapy, Pacing, and Defibrillation in Chronic Heart Failure; DINAMIT, Defibrillator in Acute Myocardial Infaction Trial; HR, hazard ratio; Cl, confidence interval; MADIT, Multicenter Automatic Defibrillator Implantation Trial; MI, myocardial infarction; NSVT, nonsustained ventricular tachycardia; SCD, sudden cardiac death; SCD-HeFT, SCD in Heart Failure Trial; DEFINITE, Defibrillators in Non-Ischemic Cardiomyopathy Treatment Evaluation; CRT, cardiac resynchronization therapy; CARE-CHF, Cardiac Resynchronization in Heart Failure Study; CASH, Cardiac Arrest Study Hamburg; CIDS, Canadian Implantable Defibrillator Study.

repolarization. This may be clinically recognized by serum hypokalemia, hypomagnesia, and progressive prolongation of the QT interval. Hypocalcemia and hypothermia also prolong the QT interval, but generally do not cause ventricular arrhythmias unless severely deranged.
Short QT: Recently, patients with a QTc interval of less than 360 milliseconds (typically $<300$ milliseconds) and a high risk of sudden death due to VF have been discovered. This phenotype is now described as congenital SQTS. ${ }^{66}$ These patients often have permanent or paroxysmal atrial 
fibrillation (24\%) and occasionally have depression of the PR interval. Mutations in five genes have been identified to cause SQTS. Quinidine can be efficacious in SQTS by prolonging the QT interval, normalizing the QT response to RR-interval change, and preventing cardiac events in some patients. ICDs are still needed for primary and secondary prevention (Table 3 ). ${ }^{67,68}$

Brugada syndrome: In 1992, a syndrome consisting of syncopal episodes and/or sudden death due to idiopathic VF in a structurally normal heart with ECG evidence of RV conduction delay was described as Brugada syndrome. ${ }^{69}$ In 1998, the genetic nature of the disease and its association to a mutation in the cardiac sodium channel gene were discovered. The syndrome has been linked to mutations in the SCN5A gene, ${ }^{70}$ which encodes the $\alpha$-subunit of the cardiac sodium channel, resulting in loss of function. However, the SCN5A gene is affected less than $30 \%$ of the time in pedigrees with the Brugada pattern, highlighting the genetic heterogeneity of the Brugada phenotype. Although it is inherited as an autosomal dominant pattern,

there is a striking male to female ratio of $8: 1$ of clinical manifestations. The estimated worldwide prevalence is $0.10 \%$, but can be as high as $3 \%$ in endemic areas of southeast Asia. ${ }^{71}$

Patients with the Brugada syndrome classically have an incomplete right bundle branch block pattern with precordial ST elevation $\geq 2 \mathrm{~mm}$ in leads V1-V3 type 1 (Figure 1 ). Subsequently, other ECG phenotypes were recognized. In type 2 Brugada pattern, the ST/T waves have $\geq 1 \mathrm{~mm}$ elevation but have a saddleback configuration and are generally accompanied with upright or biphasic $\mathrm{T}$ waves. In type 3, the $\mathrm{T}$ wave is upright and there is minimal ( $\leq 1 \mathrm{~mm})$ to no ST elevation.

Recent data suggest that loss of the action potential dome in RV epicardium but not endocardium underlies the ST-segment elevation seen in the Brugada syndrome. ${ }^{72}$ Also, electrical heterogeneity within RV epicardium leads to the development of closely coupled extrasystoles via a Phase II reentrant mechanisms, which then precipitate VT and VF.

Type 2

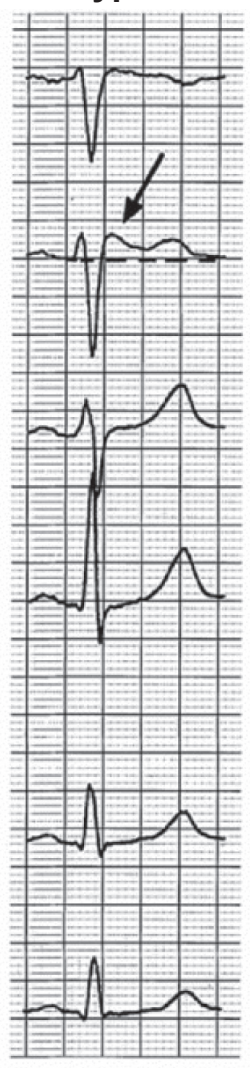

Type 3

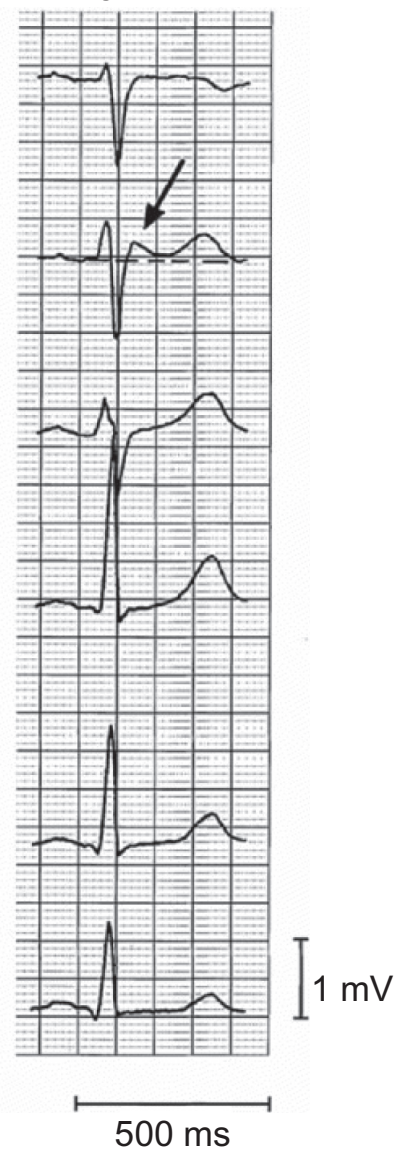

Figure I Brugada syndrome: three types of ST-segment elevation, shown mainly in the precordial leads, type I ECG pattern with pronounced elevation of the J point, a coved-type ST segment, and an inverted T wave in VI-2. Type II ECG pattern with saddleback ST-segment elevation by $>$ I mm. According to a consensus report. ${ }^{74}$ 
There are no guidelines on pharmacologic therapy for Brugada syndrome. In such patients, quinidine has been shown to prevent VF induction by electrophysiologic testing and to decrease arrhythmic event rates, ${ }^{73}$ but owing to high susceptibility to SCD, ICD implantation has been shown to prevent SCD in high-risk patients with Brugada syndrome. ${ }^{74}$ In patients with an aborted SCD, VT, or syncope, an ICD is indicated..$^{63}$ In patients without these symptoms but with a family history of SCD, ICD implant should be guided by results of provocation ${ }^{75}$ and electrophysiologic testing. ${ }^{76}$ The indications for ICD become less clear in asymptomatic patients with the Brugada pattern on ECG, and unfortunately, there is no consensus among physicians. One method for risk stratifying asymptomatic patients is with an electrophysiology study. Patients in whom a sustained ventricular arrhythmia (VF, polymorphic VT, or monomorphic VT lasting $>30$ seconds) is inducible are felt to be at high risk and may warrant ICD implantation. However, the specificity of this test in this patient population has been questioned. Thus, the management of asymptomatic patients still remains to be definitively defined.

Catecholaminergic polymorphic VT: Catecholaminergic polymorphic VT (CPVT), also called familial polymorphic $\mathrm{VT}$, is a rare disease characterized by VT with a continuously varying QRS morphology and axis. Unlike torsade de pointes, the baseline QT interval is normal in CPVT. Arrhythmias typically begin in childhood. The classic presentation is syncope, VT (generally nonsustained), or VF; reproducible with exercise, isoproterenol infusion, and emotional stress, all leading to adrenergic surges. ${ }^{77}$ Thirty percent of reported cases are familial with normal structural heart ${ }^{78}$ and have been linked to mutations in the cardiac ryanodine receptor $(R y R 2)$ gene and less commonly in the calsequestrin-2 (CASQ2) gene. More recently, CPVT has been reported in families with mutations encoding the ankyrin-B protein. ${ }^{79}$

Patients with Andersen-Tawil syndrome may have bidirectional VT upon adrenergic stimulation. ${ }^{80}$ It has been suggested that some CPVT cases can be explained by KCNJ2 mutations. This is important to consider for RYR2and CASQ2-negative patients since KCNJ2 mutations are usually associated with a more benign prognosis and sudden death is considered an exceptional event in these cases. ${ }^{81}$

Because of the catecholaminergic mechanism of triggering, $\beta$-blockers have historically been used as the mainstay of therapy. At normal doses, $\beta$-blockers successfully reduce but do not eliminate ventricular ectopy. ${ }^{82}$ Implantable defibrillators have been shown to successfully terminate ventricular arrhythmias in patients with CPVT. Therefore, recommended treatment includes prescribing the maximally tolerated dose of $\beta$-blockade to reduce frequency of arrhythmias in conjunction with ICD implantation to prevent SCD.

\section{Pathophysiology of arrhythmia}

The most common electric sequence of events in SCD is the degeneration of VT (abnormal acceleration of ventricular rate) into VF, during which disorganized contractions of the ventricles fail to eject blood effectively, often followed by asystole or pulseless electrical activity. ${ }^{7}$ Polymorphic VT or torsade de pointes may be the initial arrhythmia in patients with genetic or acquired forms of structural heart disease. ${ }^{83}$ Bradyarrhythmias or electromechanical dissociation may be the primary electrical event in advanced heart failure or in elderly patients. ${ }^{84,85}$ Among patients with ICDs, arrhythmic death accounts for $20 \%-35 \%$ of deaths, and electromechanical dissociation after shock is a frequent cause of death. ${ }^{86}$ Asystole may be the first rhythm observed in the field, but this may be a marker of the duration of arrest since coarse VF ultimately degenerates into asystole.

\section{Management}

\section{Risk stratification}

Current parameters for risk stratification of patients with CAD for SCD include medical history (presence of NSVT or syncope), EF, ECG (QRS duration, QT interval, QT dispersion), signal-averaged ECG, heart rate variability, and baroreflex sensitivity. However, the sensitivity and specificity of these parameters have yet not been studied in detail in large patient populations. The single major parameter associated with higher incidence and studied in many clinical trials is LVEF. At present, only LV dysfunction with reduced EF reliably defines "high risk" for SCD in patients with ischemic and nonischemic cardiomyopathy. The heart failure functional class and history of prior MI or CAD are also important prognostic risk factors along with sudden specific definite indications. ${ }^{44}$

\section{Prevention}

Prevention of sudden death means detection of highrisk patients and application of medical treatment in order to postpone it. The high risk of development of SCD is majorly attributed to fatal ventricular arrhythmias. Electrophysiologic anomalies in cells lead to development of ventricular ectopic activity or ventricular arrhythmias, which comes to the end with fibrillation and eventually death if not terminated in time. As survival rates for out-of-hospital cardiac arrests are extremely low, ranging from $2 \%$ to $25 \%$ in the United States, ${ }^{87}$ 
secondary prevention strategies only address a small portion of patient population at risk of SCD. The accumulated data have allowed guidelines to be formulated, which allow us to predict with more certainty the patients at risk for SCD and address the challenge to identify patients at risk before the first event as primary prevention. However, applying those guidelines in practice requires systems to structure the environment in which care is delivered so that "doing the right thing" becomes automatic. ${ }^{88}$ This requires tools that simplify and provide focus by embedding the recommendations for evidence-based care into the care itself.

\section{Pharmacologic therapy}

\section{$\beta$-blockers}

Of the different drugs that have been evaluated, only $\beta$-blockers have reduced sudden death in the MI survivor. ${ }^{89}$ The Beta-Blocker Heart Attack Trial (BHAT) study showed that $\beta$-blockade with propranolol reduced all-cause mortality by $25 \%$, especially in patients with diminished LV function and/or ventricular arrhythmias..$^{90}$ A randomized trial of nearly 46,000 patients showed that, in the acute MI setting, early oral administration of high-dose $\beta$-blocker drugs has been shown to prevent VF. ${ }^{91}$ In the Metoprolol CR/XL Randomized Intervention Trial in Congestive Heart Failure trial, 3,991 patients with NYHA class II-IV heart failure and EF $\leq 40 \%$ were randomized to long-acting metoprolol with a dose escalation protocol..$^{92}$ At 1-year follow-up, overall mortality was lower in the treated group compared to placebo (7.2\% vs $11 \%$ per patient-years of follow-up). There was also a $41 \%$ relative risk reduction in sudden death with long-acting metoprolol. These data provide unequivocal benefit of $\beta$-blockade in acute MI, post-MI, and congestive heart failure for prevention of mortality and SCD.

\section{Antiarrhythmic drugs}

The sine qua non for efficacy of common antiarrhythmic drugs in prevention against SCD based on well-designed, placebocontrolled clinical trials has shown no added benefit. ${ }^{89,93}$ Class I drugs (mexiletine, encainide, flecainide), calcium antagonists, and class III drugs ( $d$-sotalol, dofetilide) all failed to reduce or even increase the incidence of SCD after a MI. ${ }^{94}$ Amiodarone also has been shown to have no definitive effect on mortality in patients after MI in preventing SCD, as manifested in the SCD in Heart Failure Trial (SCD-HeFT) ${ }^{95}$

\section{Statins}

The role of the statins has been well studied in patients with $\mathrm{CAD}$ and has been shown to be extremely beneficial in reducing mortality, but whether they play any significant role in preventing SCD remains controversial. A Multicenter Automatic Defibrillator Implantation Trial (MADIT II) substudy ${ }^{96}$ demonstrated that, among patients treated with ICDs, those with background statin therapy had a lower rate of ventricular tachyarrhythimas. This finding was intriguing since it was unclear if this observation was due to reductions in coronary events, decreased inflammation, unique antiarrhythmic properties, or unidentified confounders. Recently, the Cholesterol Lowering and Arrhythmia Recurrences After Internal Defibrillator Implantation (CLARIDI) study demonstrated that intensive lipid-lowering therapy using $80 \mathrm{mg}$ of atorvastatin led to a $40 \%$ relative risk reduction (from $38 \%$ to $21 \%$ ) in $\mathrm{VT} / \mathrm{VF}$ recurrence in patients with ICD during a 12-month follow-up. Yet, there are no definite guidelines supporting addition of statins as adjuvant therapy for prevention of SCD beyond conventional indications.

\section{The role of ICD devices in primary and secondary prevention against SCD}

Multiple prospective, randomized, multicenter clinical trials have documented improved survival with ICD therapy in high-risk patients with LV dysfunction due to either prior MI or nonischemic cardiomyopathy. On a background of optimal medical therapy (with or without antiarrhythmic drug therapy), ICD therapy has been associated with a $23 \%-55 \%$ mortality reduction, due almost exclusively to a reduction in SCD. Superiority of an ICD over antiarrhythmic drug therapy for secondary prevention against SCD (predominantly amiodarone) was primarily noticed in the Antiarrhythmic Versus Implantable Defibrillator (AVID) trial..$^{97}$ The AVID trial enrolled 1,016 patients resuscitated from an episode of VT (if associated with hemodynamic collapse, cardiac symptoms, or occurring in the setting of an $\mathrm{EF} \leq 40 \%$ ) or VF. Patients were randomized to receive either medical therapy alone or medical therapy in conjunction with an antiarrhythmic drug, which was most commonly amiodarone. The trial was stopped prematurely when a survival benefit was noted in patients receiving ICDs compared with those treated with sotalol or amiodarone. The unadjusted survival rates for the ICD vs drug groups were $89 \%$ vs $82 \%$ at 1 year, $82 \%$ vs $75 \%$ at 2 years, and $75 \%$ vs $65 \%$ at 3 years. The major effect of the ICD was to prevent arrhythmic death $(4.7 \%$ vs $10.8 \%$ in patients treated with an antiarrhythmic drug). Results consistent with the AVID trial were also reported from the CIDS $^{98}$ and the $\mathrm{CASH}^{99}$ studies. 


\section{MADIT}

To test the efficacy of ICDs in prevention of SCD, the MADIT randomized 196 patients with ischemic cardiomyopathy, ${ }^{100}$ $\mathrm{EF} \leq 35 \%$, a documented episode of NSVT, and inducible VT on electrophysiology study to ICD $(n=95)$ vs conventional medical therapy $(n=101)$. After a mean follow-up of 27 months, the relative risk reduction for all-cause mortality in the patients receiving ICDs was $54 \%(P=0.009)$, thus showing the benefit of prophylactic ICD placement in a high-risk population.

\section{MADIT II}

However, to make an impact on the overall population at risk for sudden death, high-risk patients need to be identified before an episode of VT or fibrillation (primary prevention). The MADIT II highlighted the possibility of preventing sudden death in patients with CAD. According to this trial, patients with a previous MI and low LVEF $(\leq 30 \%)$ on optimal medical therapy were randomized to receive either an ICD or no ICD. ${ }^{96}$ Patients implanted with an ICD had mortality rate of $14.2 \%$ vs $19.8 \%$ in the conventional therapy group $(P=0.016)$, a $31 \%$ relative risk reduction in mortality during a follow-up period of 20 months. The survival benefit was entirely due to a reduction in the incidence of SCD and became apparent at 9 months after device implantation. This trial was novel in that there was no requirement for invasive electrophysiologic testing of prior ventricular arrhythmias. This trial expanded on the findings of MADIT I, which showed the superiority of ICD therapy in patients with CAD with EF $35 \%$ or less.

\section{SCD-HeFT}

The significant role of ICD therapy in primary prevention against SCD in both ischemic and nonischemic cardiomyopathy patients was further clarified by the SCD-HeFT. ${ }^{101}$ This trial enrolled 2,521 patients with NYHA $^{102}$ class II or III CHF and an EF of $\leq 35 \%$. Patients were randomized to receive optimal medical therapy alone (847 patients), optimal medical therapy along with amiodarone (845 patients), or optimal medical therapy along with a conservatively programmed, shock-only, single-lead ICD (829 patients). Placebo and amiodarone were administered in a double-blind fashion. The primary end point of the study was all-cause mortality with mean follow-up of 3.8 years. A 23\% reduction in mortality $(P=0.007)$ was observed with the ICD; the benefit of ICD was similar in both ischemic (HR, 0.79; $P=0.05)$ and nonischemic cardiomyopathy (HR, $0.73 ; P=0.06)$. In contrast, mortality was similar in patients on either medical therapy alone or medical therapy combined with amiodarone. The benefit of ICD therapy was comparable for ischemic and nonischemic cardiomyopathy.

\section{DEFINITE trial}

The Defibrillators in Non-Ischemic Cardiomyopathy Treatment Evaluation (DEFINITE) trial was the MADIT II counterpart. This trial included 458 patients with nonischemic dilated cardiomyopathy, EF $\leq 35 \%$, nonsustained VT or premature ventricular contractions, and NYHA class I, II, or III who were randomly divided to standard medical therapy or ICD. ${ }^{103}$ At a 2-year follow-up, there was a trend in mortality reduction with $\operatorname{ICD}(7.9 \%$ vs $14.1 \%$; HR, $0.65 ; P=0.08)$. The largest benefit was seen in NYHA class III patients (HR, 0.37). In part, on the basis of the results of this trial, the Centers for Medicare and Medical Services expanded coverage for ICD implementation to patients with nonischemic cardiomyopathy for more than 9 months in duration who have NYHA class III or IV heart failure and $\mathrm{EF} \leq 35 \%$.

\section{Timing of ICD implantation CABG Patch Trial}

In the CABG Patch Trial, 900 patients with LVEF of $<36 \%$ and abnormal signal-averaged ECG who were undergoing elective coronary bypass surgery were randomized to ICD or no antiarrhythmic therapy. ${ }^{104}$ This trial showed no difference in survival between the two groups at an average of 32-month follow-up. Of note, 88 patients enrolled were not randomized because they were deemed too unstable at time of surgery for ICD placement. Additionally, EFs of these patients were not assessed postoperatively. Nevertheless, results suggest that revascularization should be performed when feasible and that SCD risk stratification should be performed after revascularization.

\section{DINAMIT}

In the Defibrillator in Acute Myocardial Infarction Trial (DINAMIT), a randomized, open-label trial comparing ICD therapy to optimal medical therapy, 674 high-risk patients (defined by EF < 35\%) were enrolled 6-40 days after MI. ${ }^{105,106}$ The primary endpoint was death from any cause; death from arrhythmia was a secondary end point. During a mean follow-up of 30 months, there was no difference in overall mortality between the two treatment groups. A reduction in arrhythmia was balanced by an increase in overall mortality (cardiac but nonarrhythmogenic) in ICD group. The reason for this surprising finding is unclear but may be related to impaired cardiac autonomic function early after 
MI. The benefits of ICD therapy for prevention of SCD may not become evident until years after MI and may not have been captured in the mean 30-month follow-up of DINAMIT. Current guidelines therefore recommend deferring ICD implantation for at least 40 days following MI.

Aggressive treatment of myocardial ischemia, including revascularization, is the main treatment in these patients, and early implantation of ICD does not reduce overall mortality after early MI (DINAMIT). Implantation of ICD should be deferred in these cases as is currently recommended, with reassessment of LV function after " 40 days" to determine whether ICD is still required for primary prevention of SCD (if the LVEF $<35 \%$ ), although in some individuals circumstances it may be considered (eg, in patients with recurrent, sustained arrhythmias).

\section{Cardiac resynchronization therapy}

Cardiac resynchronization therapy (CRT), or biventricular pacing, can improve cardiac pump function in advanced heart failure by simultaneous activation of the left and right ventricles in those with underlying or pacing-induced bundle branch block. CRT ${ }^{107}$ is approved in the United States for EF $\leq 35 \%$, evidence of dyssynchrony, and class III and IV heart failure despite optimal medical therapy. A brief review of the clinical data supporting their current use is as below.

COMPANION trial: CRT with either a pacemaker or a pacemaker-defibrillator has been shown to be very beneficial in the Comparison of Medical Therapy, Pacing, and Defibrillation in Chronic Heart Failure (COMPANION) trial, ${ }^{108}$ which randomized patients with class III or IV heart failure, normal sinus rhythm, LVEF $<35 \%$, LV end diastolic volume $>60 \mathrm{~mm}$, and QRS interval $>120$ milliseconds. In this trial, CRT with a pacemaker decreased the risk of the primary endpoint (HR, $0.81 ; P=0.014)$, as did CRT with a pacemaker-defibrillator $(\mathrm{HR}, 0.80 ; P=0.01)$. The risk of the combined end point of death or hospitalization for heart failure was reduced by $34 \%$ in the pacemaker group $(P<0.002)$ and by $40 \%$ in the pacemaker-defibrillator group $(P<0.001)$. A pacemaker reduced the risk of the secondary end point of death from any cause by $24 \%(P=0.059)$, and a pacemakerdefibrillator reduced the risk by $36 \%(P=0.003)$.

CARE-CHF trial: The Cardiac Resynchronization in Heart Failure (CARE-HF) trial was a nonblinded European, which enrolled patients with class III or IV heart failure, $\mathrm{LVEF}<35 \%$, LV end diastolic volume $>30 \mathrm{~mm}$, QRS interval $>150$ milliseconds, or QRS $>120$ milliseconds with echocardiographic parameters of dyssynchrony. ${ }^{109}$ This trial confirmed the results of earlier trials that the benefits of CRT are in addition to those achieved with standard pharmacologic therapy in patients with moderate-to-severe heart failure due to LV systolic dysfunction with evidence of cardiac dyssynchrony. CARE-HF is the first trial to show benefit with CRT with respect to survival and the first to show benefit and continued improvement for a period of over 2 years.

MADIT-CRT: In a large randomized study of NYHA class I and II patients, the primary endpoint showed that CRT with an ICD (CRT-D) was associated with 34\% relative reduction in the risk of all-cause mortality or the first heart failure event; in addition, there were $41 \%$ relative reduction of heart failure events compared to patients with ICD. One-year follow-up confirmed an improvement of $11 \%$ in LVEF compared to $3 \%$ improvement for patients with ICD. ${ }^{110}$

\section{Summary of a generalized simple systematic approach toward prevention of SCD (ESCAPE pathway)}

Multiple pathways have been developed in recent past to address these complex issues faced in the management of SCD; however, most of them lack simplicity and practicality of implementation, which in turn affect their overall outcome and patient care. Here we describe the ESCAPE pathway, ${ }^{111}$ which is a simple novel pathway for primary and secondary prevention of sudden cardiac arrest, aiming to increase physician awareness and incorporate a tool for appropriate referral for ICD evaluation (Figure 2).

\section{Step A: initial evaluation of patients}

The initial and foremost thing to observe when assessing for the prevention against SCD is the EF. According to the $\mathrm{ACC} /$ American Heart Association (AHA)/ESC 2006 guidelines for the management of patients with ventricular arrhythmias and the prevention of SCD, new criteria include patients with either ischemic or nonischemic cardiomyopathy with $\mathrm{EF} \leq 35 \%$ and NYHA class II or III heart failure, removing the controversial criteria from 2003 that restricted ICDs to patients with ischemic cardiomyopathy, EF $\leq 30 \%$, and QRS $>120$ milliseconds.

On the basis of the initial evaluation of the patients with $\mathrm{EF} \leq 35 \%$, they can be divided into three subgroups: (A) includes patients with a clear indication for secondary cardiac arrest prevention, (B) includes patients who have a contraindication to ICD or have no proven benefit from ICDs for SCD prevention as per clinical data available to date, and (C) includes patients who neither have any indication for ICD placement at this time as a part of secondary prevention of SCD nor any contraindication. 


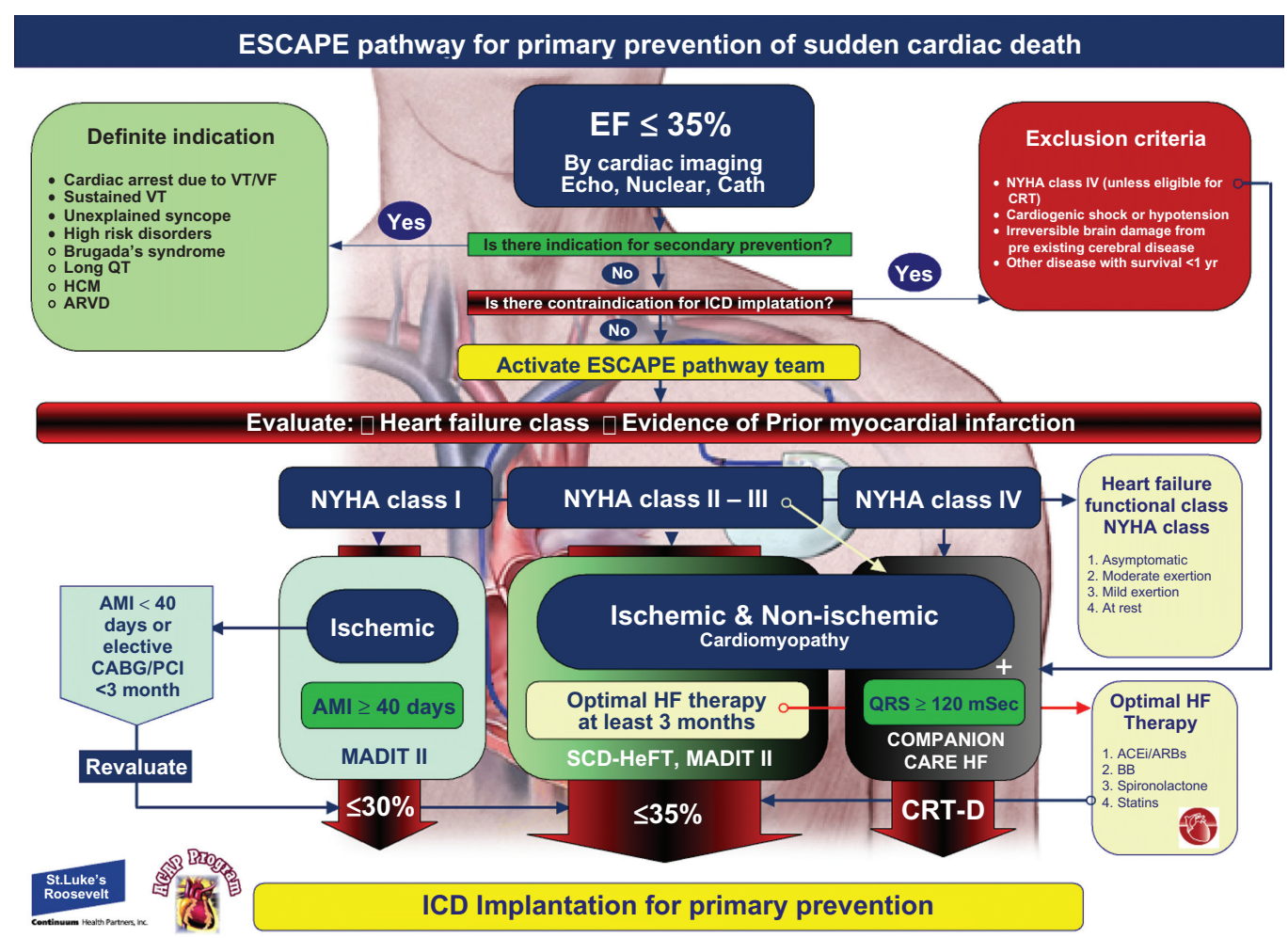

Figure 2 ESCAPE pathway. Copyright @ 2009. Reproduced with permission from Herzog E, Aziz EF, Kukin M, Steinberg JS, Mittal S. Novel pathway for sudden cardiac death prevention. Crit Pathw Cardiol. 2009;8: I-6.

Group A involves the following patients:

- Survivors of sudden cardiac arrest due to VT/VF.

- With a previous documented episode of hemodynamically destabilizing sustained VT.

- Unexplained syncope in the setting of underlying structural heart disease.

- Patients with high-risk LQTS or SQTS.

- Patients with high risk Brugada syndrome.

- Patients with high-risk HCM.

- ARVD.

This group of patient population on presentation should be referred directly for ICD implantation for secondary prevention against $\mathrm{SCD}$.

Group B involves patients with a contraindication for ICD implantation and include the following:

- NYHA class IV patients (unless QRS $\leq 120$ milliseconds who are eligible for CRT).

- Cardiogenic shock or hypotension.

- Irreversible brain damage from preexisting cerebral disease.

- Other disease (eg, cancer, uremia, liver failure), associated with a likelihood of survival less than 1 year.

Group C patients need further work-up to decide whether or when they should get ICDs and should enter into step B.
Step B: evaluation of heart failure class

To determine the best course of therapy, these patients require assessment of the stage of heart failure according to the NYHA classification. ${ }^{12,113}$

- Class I: No limitation of physical activity. Ordinary physical activity does not cause undue fatigue, palpitation, or dyspnea (shortness of breath).

- Class II: Slight limitation of physical activity. Comfortable at rest, but ordinary physical activity results in fatigue, palpitation, or dyspnea.

- Class III: Marked limitation of physical activity. Comfortable at rest, but less than ordinary activity causes fatigue, palpitation, or dyspnea.

- Class IV: Unable to carry out any physical activity without discomfort. Symptoms of cardiac insufficiency at rest. If any physical activity is undertaken, discomfort is increased.

\section{Step C: evaluation of CAD or prior MI in NYHA} class I patient

Evaluation for any evidence of prior $\mathrm{MI}$ or $\mathrm{CAD}$ requiring intervention is further necessary.

- Patients with NYHA class I heart failure whose EF is lower or equal to $30 \%$ and who are at least 40 days 
post-MI should be referred for an ICD implantation according to MADIT II trial.

- Patients with low EF and $\leq 40$ days post-MI should be managed medically for their heart failure at present. ${ }^{114}$ If repeated imaging at 40 days confirms $\mathrm{EF} \leq 30 \%$ (or $\leq 35 \%$ in patients with class II or III NYHA class $\mathrm{CHF}$ ), these patients should be referred for an ICD implantation.

- Patients with low EF who underwent elective revascularization either by percutaneous intervention or by coronary bypass surgery in $\leq 3$ months should be managed medically with optimal therapy for heart failure, and if repeated imaging at 3 months confirms EF $\leq 30 \%$ (or $\leq 35 \%$ in patients with class II or III NYHA class $\mathrm{CHF}$ ), these patients should be referred for an ICD implantation.

\section{Step D: primary prevention of SCD in NYHA class II} and III patients with low EF

According to the ACC/AHA published Update Guidelines for the Diagnosis and Management of Chronic Heart Failure in the Adult. ${ }^{113}$ This treatment includes the following:

- Angiotensin-converting enzyme (ACE) inhibitors are recommended for routine administration to symptomatic and asymptomatic patients with LV EF $\leq 40 \%$ (strength of evidence $=\mathrm{A}$ ).

- $\beta$-blockers shown to be effective in clinical trials of patients with $\mathrm{HF}$ are recommended for patients with an LVEF $\leq 40 \%$ (strength of evidence $=\mathrm{A}$ ).

- Angiotensin receptor blockers (ARBs) are recommended for routine administration to symptomatic and asymptomatic patients with an $\mathrm{LVEF} \leq 40 \%$ who are intolerant to ACE inhibitors for reasons other than hyperkalemia or renal insufficiency (strength of evidence $=\mathrm{A}$ ).

- Administration of an aldosterone antagonist should be considered in patients following an acute MI, with clinical HF signs and symptoms and an LVEF $\leq 40 \%$. Patients should be on standard therapy, including an ACE inhibitor (or ARB) and a $\beta$-blocker (strength of evidence $=\mathrm{A}$ ). If repeated imaging at 3 months confirms $\mathrm{EF} \leq 35 \%$ and still in NYHA class II and III, these patients will be referred for an ICD implantation.

Step E: primary prevention of SCD is NYHA class III and IV heart failure patients with prolonged QRS (>120 milliseconds)

Patients with QRS $\leq 120$ milliseconds and in NYHA class (III or IV) according to COMPANION and CARE-HF trial will be referred for CRT-D, where patients with NYHA class IV but QRS $>120$ milliseconds should be treated with optimal medical therapy. ${ }^{89}$

\section{Conclusion}

Over the last three decades, revolutionary advances in the understanding and treatment of SCD have been accomplished. Structural and electrical mechanisms of terminal arrhythmias have been elucidated. Over two-dozen genetic mutations and polymorphisms have been identified, which in turn have increased our understanding of ion channel structure and function. At the same time, randomized trials that demonstrated harm from antiarrhythmic drugs have curtailed the use of such drugs alone in the prevention of SCD. The ICD was developed and has proved to be a highly effective therapy in the prevention of SCD to date. Although most cases of SCD occur in patients without these high-risk features, the biggest challenge still remains: to accurately identify patients at risk for SCD for primary prevention.

\section{Disclosure}

The authors report no conflicts of interest in this work.

\section{References}

1. Seidl K, Senges J. Worldwide utilization of implantable cardioverter/ defibrillators now and in the future. Card Electrophysiol Rev. 2003; 7:5-13.

2. Myerburg RJ, Kessler KM, Castellanos A. Sudden cardiac death: epidemiology, transient risk, and intervention assessment. Ann Intern Med. 1993;119:1187-1197.

3. Zheng ZJ, Croft JB, Giles WH, Mensah GA. Sudden cardiac death in the United States, 1989 to 1998. Circulation. 2001;104:2158-2163.

4. Stevenson WG, Stevenson LW, Middlekauff HR, Saxon LA. Sudden death prevention in patients with advanced ventricular dysfunction. Circulation. 1993;88:2953-2961.

5. Chugh SS, Jui J, Gunson K, et al. Current burden of sudden cardiac death: multiple source surveillance versus retrospective death certificate-based review in a large U.S. community. J Am Coll Cardiol. 2004; 44:1268-1275.

6. Topalov V, Radisic B, Kovacevic D. [Sudden cardiac death]. Med Pregl. 1999;52:179-183.

7. Zipes DP, Wellens HJ. Sudden cardiac death. Circulation. 1998;98: 2334-2351.

8. Brugada P, Talajic M, Smeets J, Mulleneers R, Wellens HJ. The value of the clinical history to assess prognosis of patients with ventricular tachycardia or ventricular fibrillation after myocardial infarction. Eur Heart J. 1989;10:747-752.

9. Burke AP, Farb A, Malcom GT, Liang YH, Smialek J, Virmani R. Coronary risk factors and plaque morphology in men with coronary disease who died suddenly. $N$ Engl J Med. 1997;336:1276-1282.

10. Albert CM, McGovern BA, Newell JB, Ruskin JN. Sex differences in cardiac arrest survivors. Circulation. 1996;93:1170-1176.

11. Escobedo LG, Zack MM. Comparison of sudden and nonsudden coronary deaths in the United States. Circulation. 1996;93:2033-2036.

12. Friedlander Y, Siscovick DS, Weinmann S, et al. Family history as a risk factor for primary cardiac arrest. Circulation. 1998;97: $155-160$. 
13. Every N, Hallstrom A, McDonald KM, et al. Risk of sudden versus nonsudden cardiac death in patients with coronary artery disease. Am Heart J. 2002;144:390-396.

14. Barbour DJ, Warnes CA, Roberts WC. Cardiac findings associated with sudden death secondary to atherosclerotic coronary artery disease: comparison of patients with and those without previous angina pectoris and/or healed myocardial infarction. Circulation. 1987;75:II9-II11.

15. Newby KH, Thompson T, Stebbins A, Topol EJ, Califf RM, Natale A. Sustained ventricular arrhythmias in patients receiving thrombolytic therapy: incidence and outcomes. The GUSTO Investigators. Circulation. 1998;98:2567-2573.

16. Gheeraert PJ, Henriques JP, de Buyzere ML, et al. Out-of-hospital ventricular fibrillation in patients with acute myocardial infarction: coronary angiographic determinants. J Am Coll Cardiol. 2000;35:144-150.

17. Fuster V, Poon M, Willerson JT. Learning from the transgenic mouse: endothelium, adhesive molecules, and neointimal formation. Circulation. 1998;97:16-18.

18. Berger CJ, Murabito JM, Evans JC, Anderson KM, Levy D. Prognosis after first myocardial infarction. Comparison of Q-wave and nonQ-wave myocardial infarction in the Framingham Heart Study. JAMA. 1992;268:1545-1551.

19. Nazarian S, Bluemke DA, Lardo AC, et al. Magnetic resonance assessment of the substrate for inducible ventricular tachycardia in nonischemic cardiomyopathy. Circulation. 2005;112:2821-2825.

20. Eckart RE, Jones SOt, Shry EA, Garrett PD, Scoville SL. Sudden death associated with anomalous coronary origin and obstructive coronary disease in the young. Cardiol Rev. 2006;14:161-163.

21. Weinberg BA, Miles WM, Klein LS, et al. Five-year follow-up of 589 patients treated with amiodarone. Am Heart J. 1993;125: 109-120.

22. Herre JM, Sauve MJ, Malone P, et al. Long-term results of amiodarone therapy in patients with recurrent sustained ventricular tachycardia or ventricular fibrillation. J Am Coll Cardiol. 1989;13:442-449.

23. Spirito P, Seidman CE, McKenna WJ, Maron BJ. The management of hypertrophic cardiomyopathy. N Engl J Med. 1997;336:775-785.

24. Fowler SJ, Cerrone M, Napolitano C, Priori SG. Genetic testing for inherited cardiac arrhythmias. Hellenic J Cardiol. 2010;51:92-103.

25. Marian AJ, Roberts R. Molecular genetic basis of hypertrophic cardiomyopathy: genetic markers for sudden cardiac death. J Cardiovasc Electrophysiol. 1998;9:88-99.

26. Christiaans I, van Engelen K, van Langen IM, et al. Risk stratification for sudden cardiac death in hypertrophic cardiomyopathy: systematic review of clinical risk markers. Europace. 2010;12:313-321.

27. Cecchi F, Maron BJ, Epstein SE. Long-term outcome of patients with hypertrophic cardiomyopathy successfully resuscitated after cardiac arrest. J Am Coll Cardiol. 1989;13:1283-1288.

28. Elliott PM, Sharma S, Varnava A, Poloniecki J, Rowland E, McKenna WJ. Survival after cardiac arrest or sustained ventricular tachycardia in patients with hypertrophic cardiomyopathy. J Am Coll Cardiol. 1999;33:1596-1601.

29. D'Andrea A, Caso P, Cuomo S, et al. Prognostic value of intra-left ventricular electromechanical asynchrony in patients with mild hypertrophic cardiomyopathy compared with power athletes. $\mathrm{Br} J$ Sports Med. 2006;40:244-250; discussion 50.

30. D'Andrea A, Caso P, Severino S, et al. Prognostic value of intra-left ventricular electromechanical asynchrony in patients with hypertrophic cardiomyopathy. Eur Heart J. 2006;27:1311-1318.

31. Elliott PM, Gimeno JR, Tome MT, et al. Left ventricular outflow tract obstruction and sudden death risk in patients with hypertrophic cardiomyopathy. Eur Heart J. 2006;27:1933-1941.

32. Kofflard MJ, Ten Cate FJ, van der Lee C, van Domburg RT. Hypertrophic cardiomyopathy in a large community-based population: clinical outcome and identification of risk factors for sudden cardiac death and clinical deterioration. J Am Coll Cardiol. 2003;41:987-993.

33. Takagi E, Yamakado T, Nakano T. Prognosis of completely asymptomatic adult patients with hypertrophic cardiomyopathy. J Am Coll Cardiol. 1999;33:206-211.
34. Khan A, Mittal S, Sherrid MV. Arrhythmogenic right ventricular dysplasia: from genetics to treatment. Anadolu Kar+diyol Derg. 2009; 9 Suppl 2:24-31.

35. Sen-Chowdhry S, McKenna WJ. Sudden cardiac death in the young: a strategy for prevention by targeted evaluation. Cardiology. 2006;105: 196-206.

36. Bauce B, Nava A, Beffagna G, et al. Multiple mutations in desmosomal proteins encoding genes in arrhythmogenic right ventricular cardiomyopathy/dysplasia. Heart Rhythm. 2010;7:22-29.

37. Corrado D, Fontaine G, Marcus FI, et al. Arrhythmogenic right ventricular dysplasia/cardiomyopathy: need for an international registry. Study Group on Arrhythmogenic Right Ventricular Dysplasia/Cardiomyopathy of the Working Groups on Myocardial and Pericardial Disease and Arrhythmias of the European Society of Cardiology and of the Scientific Council on Cardiomyopathies of the World Heart Federation. Circulation. 2000;101:E101-E106.

38. Furlanello F, Bertoldi A, Dallago M, et al. Cardiac arrest and sudden death in competitive athletes with arrhythmogenic right ventricular dysplasia. Pacing Clin Electrophysiol. 1998;21:331-335.

39. Nava A, Bauce B, Basso C, et al. Clinical profile and long-term follow-up of 37 families with arrhythmogenic right ventricular cardiomyopathy. J Am Coll Cardiol. 2000;36:2226-2233.

40. Thiene G, Nava A, Corrado D, Rossi L, Pennelli N. Right ventricular cardiomyopathy and sudden death in young people. $N$ Engl J Med. 1988;318:129-133.

41. Nasir K, Bomma C, Tandri H, et al. Electrocardiographic features of arrhythmogenic right ventricular dysplasia/cardiomyopathy according to disease severity: a need to broaden diagnostic criteria. Circulation. 2004;110:1527-1534.

42. Dalal D, Nasir K, Bomma C, et al. Arrhythmogenic right ventricular dysplasia: a United States experience. Circulation. 2005;112: 3823-3832.

43. Gardin JM, McClelland R, Kitzman D, et al. M-mode echocardiographic predictors of six- to seven-year incidence of coronary heart disease, stroke, congestive heart failure, and mortality in an elderly cohort (the Cardiovascular Health Study). Am J Cardiol. 2001;87:1051-1057.

44. Choudhury L, Mahrholdt H, Wagner A, et al. Myocardial scarring in asymptomatic or mildly symptomatic patients with hypertrophic cardiomyopathy. J Am Coll Cardiol. 2002;40:2156-2164.

45. Moon JC, McKenna WJ, McCrohon JA, Elliott PM, Smith GC, Pennell DJ. Toward clinical risk assessment in hypertrophic cardiomyopathy with gadolinium cardiovascular magnetic resonance. J Am Coll Cardiol. 2003;41:1561-1567.

46. Reisinger J, Dubrey SW, Lavalley M, Skinner M, Falk RH. Electrophysiologic abnormalities in AL (primary) amyloidosis with cardiac involvement. J Am Coll Cardiol. 1997;30:1046-1051.

47. Dubrey SW, Bilazarian S, LaValley M, Reisinger J, Skinner M, Falk RH. Signal-averaged electrocardiography in patients with AL (primary) amyloidosis. Am Heart J. 1997;134:994-1001.

48. Gatzoulis MA, Till JA, Somerville J, Redington AN. Mechanoelectrical interaction in tetralogy of Fallot. QRS prolongation relates to right ventricular size and predicts malignant ventricular arrhythmias and sudden death. Circulation. 1995;92:231-237.

49. Maron BJ, Gohman TE, Aeppli D. Prevalence of sudden cardiac death during competitive sports activities in Minnesota high school athletes. J Am Coll Cardiol. 1998;32:1881-1884.

50. Maron BJ. Hypertrophic cardiomyopathy and other causes of sudden cardiac death in young competitive athletes, with considerations for preparticipation screening and criteria for disqualification. Cardiol Clin. 2007;25:399-414, vi.

51. Maron BJ, Thompson PD, Ackerman MJ, et al. Recommendations and considerations related to preparticipation screening for cardiovascular abnormalities in competitive athletes: 2007 update: a scientific statement from the American Heart Association Council on Nutrition, Physical Activity, and Metabolism: endorsed by the American College of Cardiology Foundation. Circulation. 2007;115: 1643-1455. 
52. Hunt DP, Tang K. Long QT syndrome presenting as epileptic seizures in an adult. Emerg Med J. 2005;22:600-601.

53. Zipes DP. The long QT interval syndrome. A Rosetta stone for sympathetic related ventricular tachyarrhythmias. Circulation. 1991;84: 1414-1419.

54. Schwartz PJ. The long QT syndrome. Curr Probl Cardiol. 1997;22: 297-351.

55. Priori SG, Schwartz PJ, Napolitano C, et al. Risk stratification in the long-QT syndrome. $N$ Engl J Med. 2003;348:1866-1874.

56. Locati EH, Zareba W, Moss AJ, et al. Age- and sex-related differences in clinical manifestations in patients with congenital long-QT syndrome: findings from the International LQTS Registry. Circulation. 1998;97: 2237-2244.

57. Zareba W, Moss AJ, Schwartz PJ, et al. Influence of genotype on the clinical course of the long-QT syndrome. International Long-QT Syndrome Registry Research Group. N Engl J Med. 1998;339:960-965.

58. Khositseth A, Tester DJ, Will ML, Bell CM, Ackerman MJ. Identification of a common genetic substrate underlying postpartum cardiac events in congenital long QT syndrome. Heart Rhythm. 2004;1:60-64.

59. Schwartz PJ, Priori SG, Spazzolini C, et al. Genotype-phenotype correlation in the long-QT syndrome: gene-specific triggers for life-threatening arrhythmias. Circulation. 2001;103:89-95.

60. Ackerman MJ, Tester DJ, Porter CJ. Swimming, a gene-specific arrhythmogenic trigger for inherited long QT syndrome. Mayo Clin Proc. 1999;74:1088-1094.

61. Jervell A, Lange-Nielsen F. Congenital deaf-mutism, functional heart disease with prolongation of the Q-T interval and sudden death. Am Heart J. 1957;54:59-68.

62. Gregoratos G, Abrams J, Epstein AE, et al. ACC/AHA/NASPE 2002 guideline update for implantation of cardiac pacemakers and antiarrhythmia devices: summary article: a report of the American College of Cardiology/American Heart Association Task Force on Practice Guidelines (ACC/AHA/NASPE Committee to Update the 1998 Pacemaker Guidelines). Circulation. 2002;106:2145-2161.

63. Priori SG, Aliot E, Blomstrom-Lundqvist C, et al. Task Force on Sudden Cardiac Death of the European Society of Cardiology. Eur Heart J. 2001;22:1374-1450.

64. Vincent GM. The molecular genetics of the long QT syndrome: genes causing fainting and sudden death. Annu Rev Med. 1998;49: 263-274.

65. Splawski I, Shen J, Timothy KW, et al. Spectrum of mutations in long-QT syndrome genes. KVLQT1, HERG, SCN5A, KCNE1, and KCNE2. Circulation. 2000;102:1178-1185.

66. Gaita F, Giustetto C, Bianchi F, et al. Short QT Syndrome: a familial cause of sudden death. Circulation. 2003;108:965-970.

67. Schimpf R, Wolpert C, Bianchi F, et al. Congenital short QT syndrome and implantable cardioverter defibrillator treatment: inherent risk for inappropriate shock delivery. J Cardiovasc Electrophysiol. 2003;14 1273-1277.

68. Giustetto C, Di Monte F, Wolpert C, et al. Short QT syndrome: clinical findings and diagnostic-therapeutic implications. Eur Heart J. 2006;27: 2440-2447.

69. Brugada P, Brugada J. Right bundle branch block, persistent ST segment elevation and sudden cardiac death: a distinct clinical and electrocardiographic syndrome. A multicenter report. J Am Coll Cardiol. 1992;20: 1391-1396.

70. Chen Q, Kirsch GE, Zhang D, et al. Genetic basis and molecular mechanism for idiopathic ventricular fibrillation. Nature. 1998;392: 293-296.

71. Fowler SJ, Priori SG. Clinical spectrum of patients with a Brugada ECG. Curr Opin Cardiol. 2009;24:74-81.

72. Gussak I, Antzelevitch C, Bjerregaard P, Towbin JA, Chaitman BR. The Brugada syndrome: clinical, electrophysiologic and genetic aspects. J Am Coll Cardiol. 1999;33:5-15.

73. Belhassen B, Glick A, Viskin S. Efficacy of quinidine in highrisk patients with Brugada syndrome. Circulation. 2004;110: 1731-1737.
74. Antzelevitch C, Brugada P, Borggrefe M, et al. Brugada syndrome: report of the second consensus conference: endorsed by the Heart Rhythm Society and the European Heart Rhythm Association. Circulation. 2005;111:659-670.

75. Krahn AD, Gollob M, Yee R, et al. Diagnosis of unexplained cardiac arrest: role of adrenaline and procainamide infusion. Circulation. 2005; 112:2228-2234

76. Ruskin JN. Role of invasive electrophysiological testing in the evaluation and treatment of patients at high risk for sudden cardiac death. Circulation. 1992;85:I152-I159.

77. Krahn AD, Klein GJ, Norris C, Yee R. The etiology of syncope in patients with negative tilt table and electrophysiological testing. Circulation. 1995;92:1819-1824.

78. Leenhardt A, Lucet V, Denjoy I, Grau F, Ngoc DD, Coumel P. Catecholaminergic polymorphic ventricular tachycardia in children. A 7-year follow-up of 21 patients. Circulation. 1995;91: $1512-1519$.

79. Mohler PJ, Splawski I, Napolitano C, et al. A cardiac arrhythmia syndrome caused by loss of ankyrin-B function. Proc Natl Acad Sci U SA. 2004;101:9137-9142.

80. Tristani-Firouzi M, Jensen JL, Donaldson MR, et al. Functional and clinical characterization of KCNJ2 mutations associated with LQT7 (Andersen syndrome). J Clin Invest. 2002;110:381-388.

81. Sansone V, Tawil R. Management and treatment of Andersen-Tawil syndrome (ATS). Neurotherapeutics. 2007;4:233-237.

82. Nguyen PT, Scheinman MM, Seger J. Polymorphous ventricular tachycardia: clinical characterization, therapy, and the QT interval. Circulation. 1986;74:340-349.

83. Huikuri H. Abnormal dynamics of ventricular repolarization - a new insight into the mechanisms of life-threatening ventricular arrhythmias. Eur Heart J. 1997;18:893-895.

84. Luu M, Stevenson WG, Stevenson LW, Baron K, Walden J. Diverse mechanisms of unexpected cardiac arrest in advanced heart failure. Circulation. 1989;80:1675-1680.

85. Pratt CM, Greenway PS, Schoenfeld MH, Hibben ML, Reiffel JA. Exploration of the precision of classifying sudden cardiac death. Implications for the interpretation of clinical trials. Circulation. 1996;93: 519-524.

86. Mitchell LB, Pineda EA, Titus JL, Bartosch PM, Benditt DG. Sudden death in patients with implantable cardioverter defibrillators: the importance of post-shock electromechanical dissociation. $J$ Am Coll Cardiol. 2002;39:1323-1328.

87. Eisenberg MS, Horwood BT, Cummins RO, Reynolds-Haertle R, Hearne TR. Cardiac arrest and resuscitation: a tale of 29 cities. Ann Emerg Med. 1990;19:179-186.

88. Cannon CP, Hand MH, Bahr R, et al. Critical pathways for management of patients with acute coronary syndromes: an assessment by the National Heart Attack Alert Program. Am Heart J. 2002;143:777-789.

89. The cardiac arrhythmia suppression trial. $N$ Engl J Med. 1989;321: $1754-1756$

90. Lampert R, Ickovics JR, Viscoli CJ, Horwitz RI, Lee FA. Effects of propranolol on recovery of heart rate variability following acute myocardial infarction and relation to outcome in the Beta-Blocker Heart Attack Trial. Am J Cardiol. 2003;91:137-142.

91. Chen ZM, Pan HC, Chen YP, et al. Early intravenous then oral metoprolol in 45,852 patients with acute myocardial infarction: randomised placebo-controlled trial. Lancet. 2005;366:1622-1632.

92. Effect of metoprolol $\mathrm{CR} / \mathrm{XL}$ in chronic heart failure: Metoprolol $\mathrm{CR} / \mathrm{XL}$ Randomised Intervention Trial in Congestive Heart Failure (MERIT-HF). Lancet. 1999;353:2001-2007.

93. Effect of the antiarrhythmic agent moricizine on survival after myocardial infarction. The Cardiac Arrhythmia Suppression Trial II Investigators. N Engl J Med. 1992;327:227-233.

94. Waldo AL, Camm AJ, deRuyter H, et al. Effect of d-sotalol on mortality in patients with left ventricular dysfunction after recent and remote myocardial infarction. The SWORD Investigators. Survival With Oral d-Sotalol. Lancet. 1996;348:7-12. 
95. Julian DG, Camm AJ, Frangin G, et al. Randomised trial of effect of amiodarone on mortality in patients with left-ventricular dysfunction after recent myocardial infarction: EMIAT. European Myocardial Infarct Amiodarone Trial Investigators. Lancet. 1997;349:667-674.

96. Moss AJ, Zareba W, Hall WJ, et al. Prophylactic implantation of a defibrillator in patients with myocardial infarction and reduced ejection fraction. N Engl J Med. 2002;346:877-883.

97. A comparison of antiarrhythmic-drug therapy with implantable defibrillators in patients resuscitated from near-fatal ventricular arrhythmias. The Antiarrhythmics versus Implantable Defibrillators (AVID) Investigators. N Engl J Med. 1997;337:1576-1583.

98. Connolly SJ, Gent M, Roberts RS, et al. Canadian Implantable Defibrillator Study (CIDS): study design and organization. CIDS Co-Investigators. Am J Cardiol. 1993;72:103F-108F.

99. Kuck KH, Cappato R, Siebels J, Ruppel R. Randomized comparison of antiarrhythmic drug therapy with implantable defibrillators in patients resuscitated from cardiac arrest: the Cardiac Arrest Study Hamburg (CASH). Circulation. 2000;102:748-754.

100. Farre J. [Implantable automatic defibrillator after MADIT and EMIAT]. Rev Esp Cardiol. 1996;49:709-713.

101. Bardy GH, Lee KL, Mark DB, et al. Amiodarone or an implantable cardioverter-defibrillator for congestive heart failure. $N \mathrm{Engl} \mathrm{J} \mathrm{Med}$. 2005;352:225-237.

102. Barshop BA, Nyhan WL, Naviaux RK, McGowan KA, Friedlander M, Haas RH. Kearns-Sayre syndrome presenting as 2-oxoadipic aciduria. Mol Genet Metab. 2000;69:64-68.

103. Ellenbogen KA, Levine JH, Berger RD, et al. Are implantable cardioverter defibrillator shocks a surrogate for sudden cardiac death in patients with nonischemic cardiomyopathy? Circulation. 2006;113: 776-782.

104. Bigger JT Jr. Prophylactic use of implanted cardiac defibrillators in patients at high risk for ventricular arrhythmias after coronary-artery bypass graft surgery. Coronary Artery Bypass Graft (CABG) Patch Trial Investigators. N Engl J Med. 1997;337:1569-1575.

105. Hohnloser SH, Kuck KH, Dorian P, et al. Prophylactic use of an implantable cardioverter-defibrillator after acute myocardial infarction. N Engl J Med. 2004;351:2481-2488.
106. Hohnloser SH, Crijns HJ, van Eickels M, et al. Effect of dronedarone on cardiovascular events in atrial fibrillation. N Engl J Med. 2009;360: 668-678.

107. New CRT technology boosts care for heart failure patients. Cardiac resynchronization therapy can provide better rhythm control and better communication with the doctor to help lower your risks. Heart Advis. 2008;11:10.

108. Bristow MR, Saxon LA, Boehmer J, et al. Cardiac-resynchronization therapy with or without an implantable defibrillator in advanced chronic heart failure. N Engl J Med. 2004;350:2140-2150.

109. Cleland JG, Daubert JC, Erdmann E, et al. The CARE-HF study (CArdiac REsynchronisation in Heart Failure study): rationale, design and end-points. Eur J Heart Fail. 2001;3:481-489.

110. Moss AJ, Hall WJ, Cannom DS, et al. Cardiac-resynchronization therapy for the prevention of heart-failure events. N Engl JMed. 2009; 361:1329-1338.

111. Herzog E, Aziz EF, Kukin M, Steinberg JS, Mittal S. Novel pathway for sudden cardiac death prevention. Crit Pathw Cardiol. 2009;8:1-6.

112. Hunt SA, Baker DW, Chin MH, et al. ACC/AHA Guidelines for the Evaluation and Management of Chronic Heart Failure in the Adult: Executive Summary A Report of the American College of Cardiology/American Heart Association Task Force on Practice Guidelines (Committee to Revise the 1995 Guidelines for the Evaluation and Management of Heart Failure): Developed in Collaboration With the International Society for Heart and Lung Transplantation; Endorsed by the Heart Failure Society of America. Circulation. 2001;104:2996-3007.

113. Hunt SA, Abraham WT, Chin MH, et al. 2009 Focused update incorporated into the ACC/AHA 2005 Guidelines for the Diagnosis and Management of Heart Failure in Adults A Report of the American College of Cardiology Foundation/American Heart Association Task Force on Practice Guidelines Developed in Collaboration With the International Society for Heart and Lung Transplantation. J Am Coll Cardiol. 2009;53:e1-e90.

114. Herzog E, Varley C, Kukin M. Pathway for the management of acute heart failure. Crit Pathw Cardiol. 2005;4:37-42.
Open Access Emergency Medicine

\section{Publish your work in this journal}

Open Access Emergency Medicine is an international, peer-reviewed, open access journal publishing original research, reports, editorials, reviews and commentaries on all aspects of emergency medicine. The manuscript management system is completely online and includes a very quick and fair peer-review system, which is all easy to use.

\section{Dovepress}

Visit http://www.dovepress.com/testimonials.php to read real quotes from published authors. 